\title{
Determination of the Volatile Fatty Acid Content in the Rumen Liquid: Comparison of Gas Chromatography and Capillary Isotachophoresis
}

\author{
Jaroslav Filípek, Rudolf Dvořák \\ Clinic of Diseases of Ruminants, Faculty of Veterinary Medicine, \\ University of Veterinary and Pharmaceutical Sciences Brno, Czech Republic
}

Received October 26, 2007

Accepted June 30, 2009

\begin{abstract}
Two analytical procedures for determining volatile fatty acids in the rumen liquid were compared: capillary isotachophoresis (ITP) and gas chromatography. Acetic acid, propionic acid, butyric and valeric acids were determined. No significant differences $(\mathrm{n}=53, P \geq 0.05)$ have been identified in the amounts of acetic and propionic acids and the results are highly consistent. For butyric acid, the method of gas chromatography yielded higher results with a constant error of approximately $0.5 \mathrm{mmol} / 1$ in the whole range of concentration. In terms of diagnostics, however, this size of error is non-significant. In the case of valeric acid a proportional error was found. Gas chromatography yielded higher values, the difference being greater for the low values while for the higher values the results are almost identical. However, valeric acid is a minor acid and its determination is of secondary significance to rumen fermentation assessment. The gas chromatography method is able to clearly differentiate between $n$ and iso forms in the case of butyric and valeric acids. It can be stated that the two analytical methods yield comparable results and both can be used for the needs of practical diagnostics.
\end{abstract}

6-aminocaproic acid, FFAP capillary column, acetic acid, butyric acid

The analysis of volatile fatty acids (VFA) - acetic, propionic, butyric and valeric acids - in the rumen is of considerable clinical and diagnostic significance. To a large degree, it characterizes the metabolism of saccharides and nitrogen substances in the ruminant forestomach environment. The VFA determination can detect different disorders already at the subclinical stage and in this way enable timely and effective action. This is especially important with regard to large-scale breeding where prevention is much more efficient and economical than subsequent treatment. Numerous production diseases are caused mainly by flaws in dietetics and feeding technology, unbalanced feed rations, organic acid surplus in silage and haylage, and feeding non-wholesome or toxic feeds to animals. It is mostly in such cases that the VFA analysis as an integral part of the metabolic profile of the rumen liquid proves irreplaceable and provides valuable evidence (Dvořák et al. 1997; Jagoš et al. 1977; Jagoš and Dvořák 1990).

The VFA determination is rather a demanding analytical procedure and typically is not part of routine diagnostics. It requires a special and relatively expensive set of devices. With regard to chemical structure of the relevant substances, there are two groups of appropriate analytical methods to consider - chromatography and electromigration. The conventional distillation methods with subsequent titration are characterized by low selectivity as well as productivity and are largely no longer in use. Of the chromatographic methods, gas chromatography (GC) is the most widely used, both with filling and capillary columns (Baše and Bartoš 1970; Ceccon 1990; Diamantis et al. 2005; Kmošt'ák and Kolouch 1988; Ewaschuk et al. 2002), whereas liquid chromatography (HPLC) is used less frequently (Wei et al. 2001; Mathew et al. 1997). Of the electromigration methods, capillary isotachophoresis (CITP) (Boček et al. 1978; Dušek et al. 2004) and capillary zone electrophoresis (CZI) (Buchberger et al. 1997) are generally used. Every individual procedure has its benefits and drawbacks. In the agricultural and veterinary practice,

Address for correspondence:

RNDr. Jaroslav Filípek, CSc.

Clinic of Diseases of Ruminants

Faculty of Veterinary Medicine

University of Veterinary and Pharmaceutical Scienceas

Palackého 1-3, 61242 Brno, Czech Republic 
whether for VFA determination in the rumen liquid or silage, the GC and CITP methods are most widely used. Of them, the GC methods have been used longer, for more than half a century. Since the 1970s, due to their elegant simplicity, also the electromigration methods have become increasingly used in this area.

Given the fact that most laboratories are restricted to using only one of the above described methods, we were interested in the degree of comparability of their results. Therefore, we compared the results of VFA determination obtained using the two most widespread methods - gas chromatography (with a capillary column) and capillary isotachophoresis. We have not found any such comparison in the available literature, although we consider this very important: should any significant differences be found, the measured results would then have to be evaluated in relation to the analytical method used.

\section{Materials and Methods}

Analyzed samples

The rumen liquid $(n=53)$ was sampled by a stomach tube and filtered through an ordinary sieve in the standard way. Approximately $10 \mathrm{ml}$ of the sample was preserved with 2-3 drops of toluene to prevent fermentation. The samples preserved in this way were immediately analyzed or stored at $-20{ }^{\circ} \mathrm{C}$ temperature pending analysis.

For the ITP analysis, the samples were thoroughly centrifuged (or filtered) and $\times 200$ diluted in distilled water. Prepared in this way, the samples were used for the analysis without any further treatment.

For the gas chromatography (GC) analysis, the samples were prepared in the following way: $200 \mu 1$ of metaphosphoric acid (25\%) and formic acid (3:1) mixture was added to $1 \mathrm{ml}$ of rumen liquid (Cottyn and Boucque 1968). After 30 min of centrifugation, the clear supernantant was $\times 10$ diluted in water and injected in the chromatograph.

Chemicals used

Metaphosphoric acid, $\varepsilon$-aminocaproic acid (EACA), hydroxyethylcellulose (HEC), caproic acid - SigmaAldrich, $\mathrm{CR}, \mathrm{HCl}$ - refined by isothermic distillation, formic acid (Lachema Brno, CR). Standard solutions of appropriate concentration were prepared from the individual substances of analytical purity (Sigma-Aldrich, CR).

CITP Analysis

The analyses were carried out in a two-capillary isotachophoretic analyser IONOSEP 2002 (RECMAN Laboratory technology, CR). The internal diameter of the pre-separation capillary was $0.60 \mathrm{~mm}$ and that of the analytical capillary $0.25 \mathrm{~mm}$. Detection was carried out with contactless high-frequency conduction detectors. The leading electrolyte $-10 \mathrm{mM} \mathrm{HCl}+22 \mathrm{mM} \mathrm{EACA}+0.05 \% \mathrm{HEC}(\mathrm{pH} 4.5)$. The terminal electrolyte $5 \mathrm{mM}$ caproic acid. The driving power in the pre-separation capillary $-120 \mu \mathrm{A}$, in the analytical capillary $40 \mu \mathrm{A}$, during the detector passage $-20 \mu \mathrm{A}$. Thirty $\mu \mathrm{l}$ of sample were applied per column using an autosampler. The analysis time was approximately $20 \mathrm{~min}$.

\section{GC Analysis}

The analyses were conducted on a $6820 \mathrm{GC}$ System gas chromatograph, Agilent Technologies. A FFAP capillary column was used, $30 \mathrm{~m} \times 250 \mu \mathrm{m} \times 0.25 \mu \mathrm{m}$ (Quadrex Corporation). Carrier gas - nitrogen, flow $1.0 \mathrm{ml} / \mathrm{per} \mathrm{min}$, detector - FID, temperature programme used: $60-200{ }^{\circ} \mathrm{C}\left(20^{\circ} \mathrm{C} / \mathrm{min}, 10 \mathrm{~min}\right)$, injector $-250{ }^{\circ} \mathrm{C}$, detector $300^{\circ} \mathrm{C}$. The injector was equipped with a glass liner of glass wool to separate particles of dirt from the sample.

The samples were dosed by a HT 300A automatic dosing device at an injection size of $1 \mu$ using the split method and a 30:1 splitting ratio. The analysis time is approximately $15 \mathrm{~min}$.

\section{Statistical analysis}

Results were expressed as mean, standard deviation (S.D.), parameters of regression lines and Sudent's paired $t$-test was used. Non significant differences were defined at $p \geq 0.05$.

\section{Results}

The separation of individual substances was very good in both cases and all the acids are clearly differentiated. When CITP is used, a phosphate zone appears near the lactic acid, yet the separation of the two zones is sufficient. The GC method used for butyric and valeric acids also separates their $n$ and iso forms. No such separation happens within the CITP application. This is one of the GC advantages and if $i$ so forms assessment is needed, the GC method has to be used.

Table 1 summarizes statistical processing of the measured results. The results for acetic 
Table 1. Comparison of individual volatile fatty acid concentrations ( $\mathrm{mmol} / \mathrm{l})$ determined by capillary isotachophoresis (CITP) and gas chromatography (GC) methods

\begin{tabular}{|c|c|c|c|c|c|c|c|c|}
\hline & \multicolumn{2}{|c|}{ Acetic acid } & \multicolumn{2}{c|}{ Propionic acid } & \multicolumn{2}{c|}{ Butyric acid } & \multicolumn{3}{c|}{ Valeric acid } \\
\hline $\mathrm{n}=53$ & CITP & GC & CITP & GC & CITP & GC & CITP & GC \\
\hline Mean & 66.41 & 66.65 & 28.54 & 28.40 & 13.85 & 14.43 & 3.09 & 3.59 \\
\pm S.D. & 10.28 & 10.61 & 6.57 & 6.83 & 2.83 & 3.05 & 0.75 & 0.83 \\
\hline$P$ & N.S. & & N.S. & & 0.001 & & 0.001 & \\
\hline
\end{tabular}

Table 2. Coefficients of regression lines of statistical comparison of individual volatile fatty acids determined by capillary isotachophoresis (CITP) and gas chromatography (GC) methods

\begin{tabular}{|l|c|c|c|}
\hline \multirow{2}{*}{$\begin{array}{l}\text { Analyte } \\
\mathrm{n}=53\end{array}$} & \multicolumn{3}{|c|}{ Coefficients of the regression line } \\
\cline { 2 - 4 } & $\mathrm{a}$ & $\mathrm{b}$ & $\mathrm{r}$ \\
\hline Acetic acid & 0.873 & 0.99 & 0.9591 \\
\hline Propionic acid & 0.387 & 1.011 & 0.9812 \\
\hline Butyric acid & 0.316 & 1.017 & 0.9582 \\
\hline Valeric acid & 0.876 & 0.854 & 0.8362 \\
\hline
\end{tabular}

$\mathrm{c} G C=\mathrm{a}+\mathrm{b} \mathrm{c} C I T P$ and propionic acids were highly consistent and no significant differences between the two methods were found. This was a very positive finding, since the two majority acids make up the greatest part of the total VFA and most pathological conditions are accompanied by changes in concentrations of just these substances. In addition, the regression straight line indicators and correlation coefficients (see Table 2) indicate a very close relationship between the results of the two measurements. Figs 1 and 2 demonstrate a close correspondence of the results, the regression line and the "identity line" $(Y=X \rightarrow a=0, b=1)$ being almost identical in these

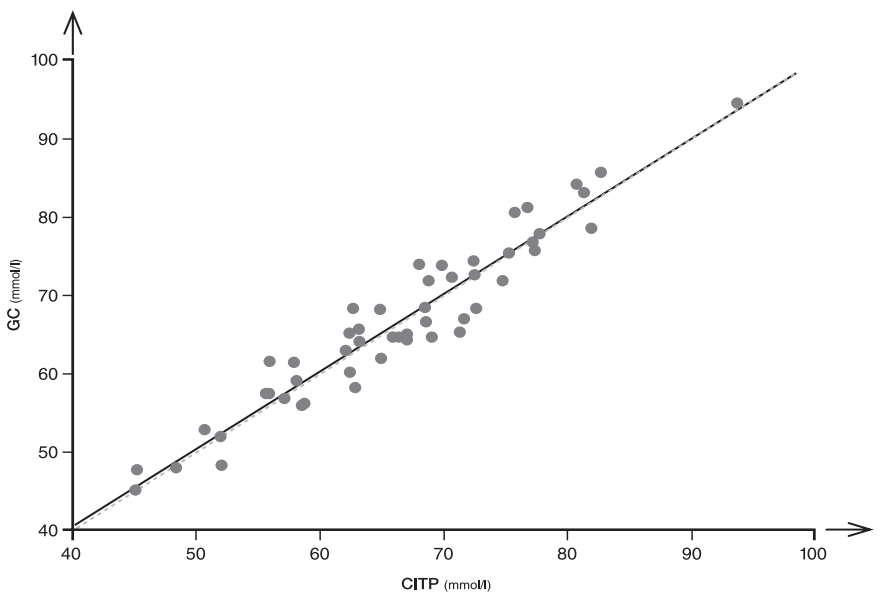

Fig. 1. Graphic comparison of volatile fatty acid concentrations determined by capillary isotachophoresis (CITP) and gas chromatography (GC) methods dispersion charts $(\mathrm{n}=53), 1$ - acetic acid peaks can be considered where an unknown substance from the sample matrix manifests a chromatographic behaviour identical to the analyte and in this way increases the resulting value. It follows from Fig. 3 that this increase is approximately constant for butyric acid in the whole range of concentration (the regression line is almost parallel to the "identity line"), which supports this idea. Verifying this possibility would involve the use of different separation conditions that is even a different chromatographic column, which goes beyond the scope of this work. Although the differences were statistically relevant, an average difference of about $0.4-0.6 \mathrm{mmol} / \mathrm{l}$ was not clinically relevant to the degree that would affect 

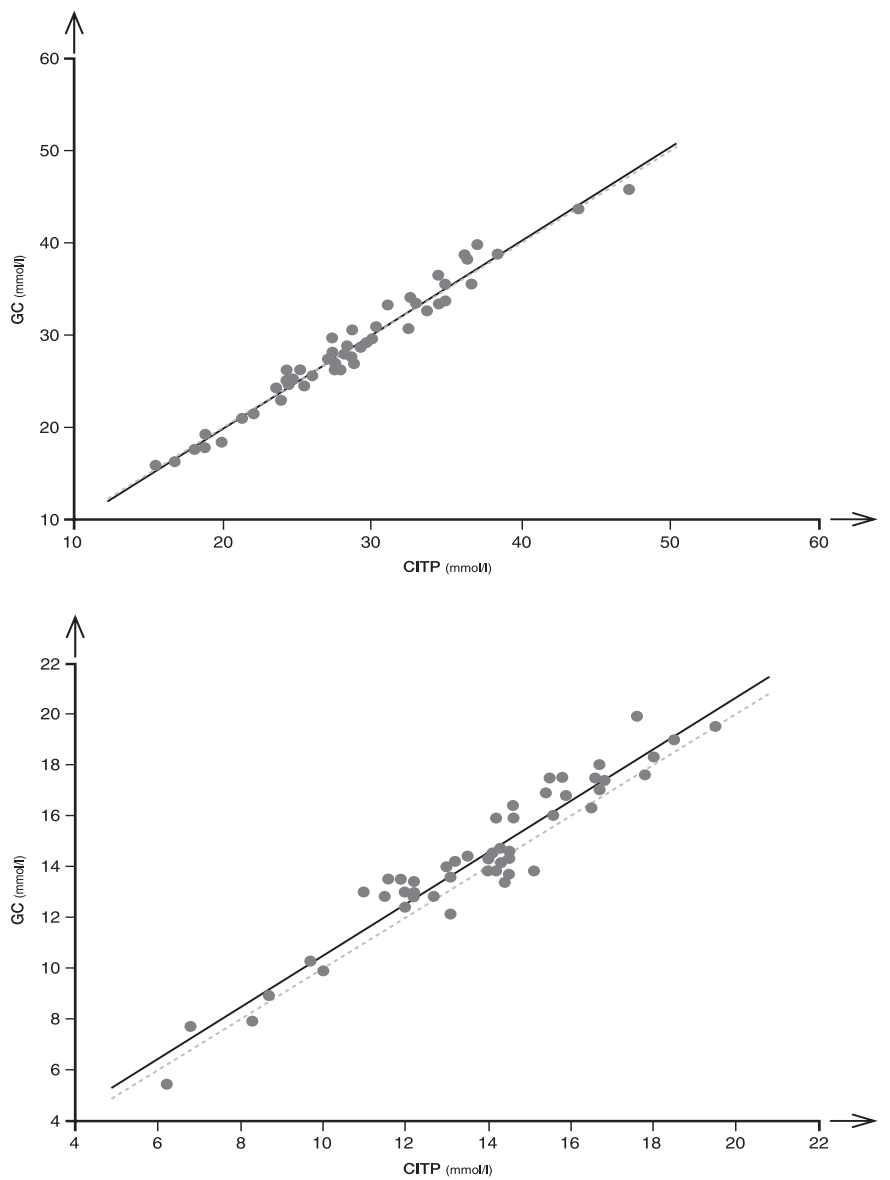

Figs 2 and 3. Graphic comparison of volatile fatty acid concentrations determined by capillary isotachophoresis (CITP) and gas chromatography (GC) methods dispersion charts $(n=53), 2$ - propionic acid, 3 - butyric acid the result interpretation in relation to standard or pathological values. As the standard values for butyric acid are within the range of 10-20 $\mathrm{mmol} / \mathrm{l}$, the difference causes an increase of some $5 \%$ in a $10 \mathrm{mmol} / \mathrm{l}$ value and only a $2.5 \%$ increase in a $20 \mathrm{mmol} / \mathrm{l}$ value, which nears the limit of reproducibility of the method itself. Identification of significance is in this case determined by a relatively high number of measurements $(\mathrm{n}=$ 53), so that even with a small effect achieved the result was considered as significant. The GC method does clearly differentiate between $n$ - and iso- forms in the two acids. In the electrolyte system used, the CITP method will not distinguish the two forms and determine this acid as a sum of both forms. This may also be the cause of 'slight' differences between the results. Though in the literature some modifications are described of e.g. alcohol addition to electrolytes leading to distinguishing of $n$ - and iso-forms of butyric acid in sugar-making solutions (Kvasnicka et al. 1993), this rather complicates the preparation of those solutions and our experience with rumen liquid analyses has not been convincing in this respect. However, this differentiation is not even necessary for practical evaluation of the current status of rumen fermentation, as $i s o$ - form of the butyric acid only constitutes several per cent of the total butyric acid and an increase only takes place in the major $n$-forms in most cases.

Valeric acid is a minor acid forming a maximum of $5 \%$ of the total VFA. In this case, the differences between the two methods were the greatest, the GC method yielding significantly higher results. The regression line equation shows that the difference between the results decreases as the values increase. E.g. for a value of 3.0 (CITP) the GC results are higher in value by approximately $20 \%$, for 4.0 they increase by approximately $15 \%$ and for a value of 6.0 the results are practically the same. The effect is obvious from Fig. 4 at first sight. As regards a possible explanation of these results, we can consider that, as in the case of butyric acid, with GC used the complete separation 


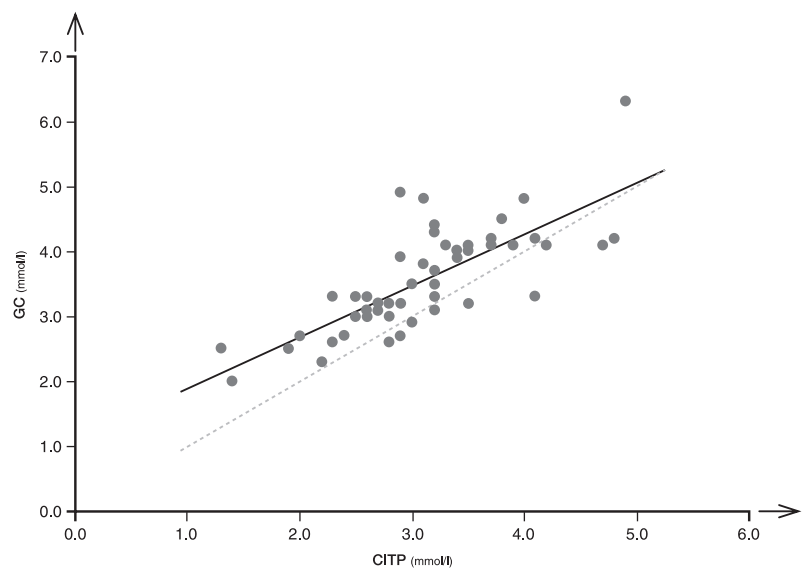

Fig. 4. Graphic comparison of volatile fatty acid concentrations determined by capillary isotachophoresis (CITP) and gas chromatography (GC) methods - dispersion charts $(n=53)$ 4 - valeric acid

analytical methods based on completely different principles.

Gas chromatography is a separation method that separates substances based on their differing affinities to the stationary phase affected by the flowing mobile phase. The mobile phase is gas, the stationary one is a glass sorbent-filled column used with the filling columns, or a thin layer of embedded liquid on the capillary's inner wall used with the capillary columns. The affinity of a substance to the stationary phase is primarily influenced by polarity.

The first successful separation of the lower fatty acids (in the ester form) by means of gas chromatography was accomplished more than half a century ago (James and Martin 1952). The following dynamic development of this analytical method as regards both its technical conditions and separation media used advanced to the present stage where we can identify the lower fatty acids through direct injecting without derivatisation required. For this purpose a range of water-resistant sorbents have been developed, some of which are able to also identify butyric acid in a single injection, i.e. a substance with rather different physically-chemical properties, but also valued in relation to assessing the condition of rumen fermentation (Fussell and McCalley 1987; Steverink 1984; Supelco 1996). At present, extensive literature on this subject testifies to an ever growing interest in identifying these substances in a wide range of materials (Yang and Choong 2001; Henders on and Steedman 1982). The advantage of the capillary columns consists in their higher sensitivity and much more advanced separation of individual acids.

Isotachophoresis belongs to the group of electrophoretic procedures. It is based on the mobility of charged particles in the electrical field, which depends on the size of charge of the particle and its mass.

In order to identify carboxyl acids with the CITP method, several electrolyte systems are used in practice. The selection of the leading electrolyte is essentially determined by the dissociation invariables of the substances that we want to separate $\left(\mathrm{pK}_{\mathrm{a}}\right.$ : acetic acid -4.76 , propionic acid 4.85, butyric acid 4.82). A pH value of the leading electrolyte must therefore be near this area. For example $\beta$-alanine, EACA or urotropine are quite frequently used. The end electrolyte is chosen based on the acids that we want to identify; 
caproic acid or MES (4-morpholineethansulfonic acid) are among the most frequently used. Through the right choice of an electrolyte system we can therefore achieve successful separation of exactly those substances that are of greatest interest to us. The CITP method advantage is that a single analysis enables identifying of a number of other useful substances at the same time, without any requirements for sample modification, e.g. lactic acid, pyruvic acid, formic acid, oxalic, citric or succinic acids and others, some of them useful for the rumen diagnostics. The electrolyte system (EACA, pH 4.5) selected by us is rather widely used and suitable for reliable analyzing of all the important components. The method's sensitivity is satisfactory at usual concentrations whereas at very low concentrations of e.g. lactic acid (values in the real sample below $0.5 \mathrm{mmol} / \mathrm{l}$ ) the identification can be repeated using a less diluted sample. Still such values are within normal limits and from the diagnostic point of view are basically irrelevant.

Therefore CITP is an appropriate method for analyzing the volatile fatty acids in the rumen. It reliably detects all diagnostically valuable components, does not require any pre-treatment of the sample (except for centrifugation and dilution of the sample with water), and due to considerable dilution of the electrolyte solutions the need for chemicals is low. On the other hand, the CITP method generally requires very exacting levels of purity of the used chemicals (sometimes even PA purity is insufficient and re-purification is necessary), and also the used distilled water must be given careful attention (underestimation of these factors will result in impurity zones that may interfere with the analysis). Some of the widespread electrolyte systems can now be obtained commercially.

It is interesting to learn that such a high level of consistency has been found in the methods based on the separation principles differing to such an extent.

Rimanoczyne and Nagy (1991) compared the identifications of acetic, propionic and butyric acids by the methods of gas and liquid chromatography in different biological materials (including the rumen liquid) without identifying any significant differences.

It can be concluded that identification of the described substances by modern separation procedures yields essentially identical results and no special attention needs to be given to the analytical method used when interpreting the findings.

\section{Stanovení těkavých mastných kyselin v bachorové tekutině: srovnání plynové chromatografie a kapilární isotachoforézy}

Byly srovnány dva analytické postupy pro stanovení těkavých mastných kyselin v bachorové tekutině - plynová chromatografie a kapilární izotachoforéza. Stanovovány byly kyselina octová, propionová, máselná a valerová. V př́ípadě kyseliny octové a propionové nebyly nalezeny významné rozdíly $(\mathrm{n}=53, P \geq 0.05)$ a výsledky byly ve velmi dobré shodě. $\mathrm{V}$ prrípadě kyseliny máselné metoda plynové chromatografie dávala výsledky vyšší s konstantní chybou cca $0.5 \mathrm{mmol} / 1 \mathrm{v}$ celém koncentračním rozsahu. $\mathrm{Z}$ hlediska diagnostiky jde o chybu zanedbatelnou. V prŕípadě kyseliny valerové byla nalezena chyba proporcionální. Plynová chromatografie dávala vyšší výsledky, rozdíl se projevuje výrazněji v nižších hodnotách, ve vyšších hodnotách se výsledky prakticky scházejí. Kyselina valerová je však kyselinou minoritní a její stanovení pro posouzení bachorové fermentace má druhořadý význam. Metoda plynové chromatografie je schopna rozlišit u kyseliny máselné a valerové $n$ a iso formu. Obecně lze konstatovat, že oba způsoby analýzy dávají srovnatelné výsledky a pro potřeby praktické diagnostiky lze používat obě uvedené metody.

\section{Acknowledgements}

This work is part of the solution of Project MSM 6215712403. 


\section{References}

Baše J, Bartoš S 1970: Stanovení TMK v krvi a bachorové tekutině přežvýkavců plynovou chromatografií. In Czech. (Determination of VFA in blood and rumen fluid of ruminants by gas chromatography). Živoč výroba 15: $369-376$

Boček P, Pavelka S, Grígelová K, Deml M, Janák J 1978: Determination of lactic and acetic acids in silage extracts by analytical isotachophoresis. J Chromatogr 154: 356-359

Buchberger W, Klampfl CHW, Eibensteiner F, Buchgraber K 1997: Determination of fermenting acids in silage by capillary electrophoresis. J Chromatogr A 766: 197-203

Ceccon L 1990: Quantitative determination of free volatile fatty-acids from dairy-products on a Nukol capillary column. J Chromatogr 519: 369-378

Cottyn BG, Boucque CHV 1968: Rapid method for the gas-chromatographic determination of volatile fatty acids in rumen fluid. J Agr Food Chem 16: 105-107

Diamantis V, Melidis P, Aivasidis A 2005: Continuous determination of volatile products in anaerobic fermenters by on-line capillary gas chromatography. Anal Chim Acta 573-574: 189-194

Dušek M, Kvasnička F, Moravcová J 2004: Determination of organic acids in silage by capillary isotachophoresis and capillary zone electrophoresis. Chem Listy 98: 418-422

Dvořák R, Hofírek B, Bouda J, Doubek J 1997: Current possibilities of examining rumen fluid and urine within diagnosing selected ruminant diseases. Veterinářství 2: 66-68

Ewaschuk JB, Zello GA, Naylor JM, Brocks DR 2002: Metabolic acidosis: separations methods and biological relevance of organic acid and lactic acid enantiomers. J Chromatogr B 781: 39-56

Fussell R J, McCalley DV 1987: Determination of volatile fatty acids (C2-C5) and lactic acid in silage by gas chromatography. Analyst 112: 1213-1216

Henderson MH, Steedman TA 1982: Analysis of C2 - C6 monocarboxylic acids in aqueous solution using gas chromatography. J Chromatogr A 244: 337-346

Jagoš P, Dvořák R 1990: Disorders of metabolic processes in rumen. In: Vrzgula L et al.: Disorders of metabolic processes in farm animals and their prevention. Bratislava, Príroda 1990, pp. 339-396

Jagoš P, Šupíková M, Dvořák R 1977: Analysis of volatile fatty acids in rumen fluid by gas chromatography. Veterinářství XVII, 10: 465-466

James AT, Martin JP 1952: Gas-liquid partition chromatography: the separation and micro-estimation of volatile fatty acids from formic acid to dodecanoic acid. Biochem J 50: 679-690

Kmošt'ák S, Kolouch F 1988: Use of the method of determination of volatile fatty acids and butyric acid in the rumen fluid by gas chromatography. Biol Chem Vet 24: 77-82

Kvasnička F, Parkin G, Harvey C 1993: Capillary isotachophoresis as a new tool in sugar factory analysis. Int Sugar J 95: 451-458

Mathew S, Sagathevan S, Thomas J, Mathen G 1997: An HPLC method for estimation of volatile fatty acids in ruminal fluid. Indian J Anim Sci 67: 805-807

Rimanoczyne SA, Nagy G 1991: Determination of volatile fatty-acids in biological samples by high-performance liquid-chromatography. Magy Allatorv Lapja 46: 237-242

Steverink ATG 1984: Gas-chromatographic method for the determination of volatile fatty-acids (C1 - C7) and lactic acid. Analyst 109: 179-180

Supelco 1996. Bulletin 856B: 1-7

Wei MC, Chang CT, Jen JF 2001: Determination of organic acids in fermentation products of milk with high performance liquid chromatography. Chromatographia 54: 601-605

Yang MH, Choong YM 2001: A rapid gas chromatographic method for direct determination of short-chain (C2C12) volatile organic acids in foods. Food Chem 75: 101-108 
